\title{
W SPRAWIE LĄCZENIA MANDATU POSŁA DO PARLAMENTU EUROPEJSKIEGO Z FUNKCJĄ CZLONKA RADY NADZORCZEJ TOWARZYSTWA UBEZPIECZEŃ WZAJEMNYCH
}

Posłowie do Parlamentu Europejskiego nie podlegają zakazom w zakresie prowadzenia działalności gospodarczej, jakie obowiązują posłów i senatorów, m.in. zakazom ustalonym w art. 34 ustawy z dnia 9 maja 1996 r. o wykonywaniu mandatu posła i senatora. W związku z tym nie ma przeszkód, by eurodeputowany pozostawał członkiem rady nadzorczej przedsiębiorcy, jakim jest towarzystwo ubezpieczeń wzajemnych, np. Towarzystwo Ubezpieczeń Wzajemnych.

Słowa kluczowe: poseł, Parlament Europejski, łączenie stanowisk, rada nadzorcza, ubezpieczenia, działalność gospodarcza

\section{ON COMPATIBILITY OF THE MANDATE OF THE DEPUTY TO THE EUROPEAN PARLIAMENT WITH THE FUNCTION OF A MEMBER OF THE SUPERVISORY BOARD OF THE ASSOCIATION OF MUTUAL INSURANCE}

Deputies to the European Parliament are excluded from prohibitions related to conducting business activity which apply to Deputies and Senators, i.a., prohibitions established in Article 34 of the Act of 9 May 1996 on Exercising the Mandate of a Deputy or Senator. Hence, there are no impediments for a Deputy to the European Parliament to remain a member of the supervisory board of an entrepreneur such as an association of mutual insurance, e.g. Association of Mutual Insurance TUW.

Key words: Deputy, European Parliament, compatibility of functions, supervisory board, insurance, business activity

\footnotetext{
* Opinia została napisana 7 lutego 2019 r. (przyp. red.).
} 


\section{TEZA OPINII}

W związku z tym, że do posłów do Parlamentu Europejskiego [dalej: PE] nie mają zastosowania zakazy tzw. niepołączalności materialnej ustalone dla posłów do Sejmu RP oraz senatorów, nie ma przeszkód, aby eurodeputowany pozostawał członkiem rady nadzorczej przedsiębiorcy, jakim jest towarzystwo ubezpieczeń wzajemnych (w tym np. Rady Nadzorczej Towarzystwa Ubezpieczeń Wzajemnych; dalej też: TUW).

\section{PRZEDMIOT OPINII}

Przedmiotem opinii jest odpowiedź na wątpliwość sformułowaną w następujący sposób: Czy w związku z objęciem mandatu posła do PE zachodzi zakaz łączenia stanowisk w przypadku sprawowania funkcji w Radzie Nadzorczej Towarzystwa Ubezpieczeń Wzajemnych?

\section{STATUS PRAWNY TOWARZYSTWA UBEZPIECZEŃ WZAJEMNYCH}

Zgodnie z art. 5 ust. 2 oraz art. 6 statutu TUW, podmiot ten organizuje i prowadzi działalność ubezpieczeniową oraz prowadzi działalność reasekuracyjną, przy czym na podstawie art. 1 ust. 1 ubezpiecza swoich członków na zasadzie wzajemności².

TUW jest zakładem ubezpieczeń działającym jako towarzystwo ubezpieczeń wzajemnych ${ }^{3}$, o którym mowa w art. $102^{4}$ ustawy z dnia 11 września 2015 r. o działalności ubezpieczeniowej i reasekuracyjnej (tekst jedn. Dz.U. z 2019 r. poz. 381, ze zm.). Towarzystwo ubezpieczeń wzajemnych podlega wpisowi do rejestru przedsiębiorców na podstawie art. 36 pkt 12 ustawy z dnia 20 sierpnia 1997 r. o Krajowym Rejestrze Sądowym (tekst jedn. w Dz.U. z 2018 r. poz. 986, ze zm.) $)^{5}$

Co prawda wpis do rejestru przedsiębiorców nie stanowi konstytutywnej cechy uzyskania przymiotu przedsiębiorcy, to jednak w kontekście art. 3 i 4 ustawy z dnia 6 marca 2018 r. — Prawo przedsiębiorców (tekst jedn. Dz.U. z 2019 r., poz. 1292), art. 805 k.c. oraz postanowienia art. 24 ust. 2 statutu TUW ${ }^{6}$ można stwierdzić, że TUW posiada status podmiotu prowadzącego działalność gospodarczą, czyli przedsiębiorcy. Nie jest to jednak kwestia bezdyskusyjna.

Konstrukcja prawna towarzystw ubezpieczeniowych oparta na zasadzie wzajemności oznacza, że głównym celem działalności takiego podmiotu nie powinna być

2 Vide tekst jednolity statutu na stronie <http://www.tuw.pl>, dostęp 26 VII 2019.

3 „Art. 6. 1. Zakład ubezpieczeń może wykonywać działalność ubezpieczeniową wyłącznie w formie spółki akcyjnej, towarzystwa ubezpieczeń wzajemnych albo spółki europejskiej określonej w rozporządzeniu Rady (WE) nr 2157/2001 z dnia 8 października 2001 r. w sprawie statutu spółki europejskiej (SE)" (Dz.Urz. WE L 294 z 10.11.2001, s. 1, ze zm.; Dz. Urz. UE polskie wydanie specjalne, rozdz. 6, t. 4, s. 251).

4 „Art. 102. Zakład ubezpieczeń, który ubezpiecza swoich członków na zasadzie wzajemności, jest towarzystwem ubezpieczeń wzajemnych".

5 KRS: 0000033284, PKD 65.12.Z. Pozostałe ubezpieczenia osobowe oraz ubezpieczenia majątkowe vide <http:/www.krs-online.com.pl/towarzystwo-ubezpieczen-wzajemnych-tuw-krs-31259.html>, dostęp 26 VII 2019.

${ }^{6}$ Art. 24 ust. 2 statutu TUW, ,Towarzystwo może zawierać umowy ubezpieczenia z osobami nie będącymi członkami Towarzystwa. Osoby te nie posiadają praw wynikających z członkostwa”. 
chęć uzyskania jak najwyższych wyników finansowych, lecz zaspokojenie potrzeb ich członków. W czasie kiedy obowiązywała ustawa z dnia 22 maja 2003 r. o działalności ubezpieczeniowej (Dz.U. z 2015 r. poz. 1206, 1273 i 1348), w literaturze przedmiotu stwierdzono, że towarzystwo ubezpieczeń wzajemnych prowadzi działalność, która nie jest nastawiona na zysk (non profit), chociaż powinna być ona opłacalna ${ }^{7}$. Postrzeganie towarzystw ubezpieczeń wzajemnych jako instytucji non profit sprawia, że nie można im przyznać statusu przedsiębiorcy, ponieważ jedną z cech działalności gospodarczej jest jej zarobkowy charakter. W nowszym piśmiennictwie uznano, że ogólne założenie konstrukcji prawno-ekonomicznej towarzystw ubezpieczeń wzajemnych wskazujące na przewagę elementów osobowych nad kapitałowymi przeszło jednak ewolucję, która uwidacznia się w odwróceniu trendów. Współcześnie działające towarzystwa charakteryzują się wyraźną przewagą elementów kapitałowych nad osobowymi, co bezpośrednio przekłada się na realizację zasady wzajemności ${ }^{8}$.

Możliwość funkcjonowania modelu kapitałowego w towarzystwach ubezpieczeń wzajemnych wynika z regulacji ustawowej, pozwalającej na wprowadzenie do statutu postanowienia, które nie wymaga powiązania członkostwa w towarzystwie z zawarciem umowy ubezpieczenia9. Taką regulacją był art. 44 ustawy z dnia 22 maja $2003 \mathrm{r}$. o działalności ubezpieczeniowej (tekst jedn. Dz.U. z 2015 r. poz. 206, ze zm.) i jest będący jego powtórzeniem art. 111 ustawy z dnia 11 września 2015 r. o działalności ubezpieczeniowej i reasekuracyjnej ${ }^{10}$. W związku z tym przepisem funkcjonowanie towarzystwa staje się zbliżone do działalności spółki akcyjnej oferującej ubezpieczenia „komercyjne”. Zgodnie z art. 24 ust. 2 statutu TUW, „Towarzystwo może zawierać umowy ubezpieczenia z osobami nie będącymi członkami Towarzystwa. Osoby te nie posiadają praw wynikających z członkostwa". Postanowienie to wskazuje na komercyjny (zarobkowy) charakter działalności TUW.

Można również zwrócić uwagę na pojawiające się w doktrynie spory na temat charakteru prawnego towarzystwa ubezpieczeń wzajemnych i możliwości zaliczenia go do spółek kapitałowych bądź spółdzielni1 ${ }^{11}$, a także na aspekt statusu członka takiego

7 Vide M. Szczepańska, Ubezpieczenia na życie. Aspekty prawne, Warszawa 2008, za: Ubezpieczenia w gospodarce rynkowej, red. A. Wąsiewicz, Bydgoszcz 1997, s. 34.

${ }^{8}$ M. Kuchlewska, ,,Odwzajemnianie” towarzystw ubezpieczeń wzajemnych w Polsce, „Rozprawy Ubezpieczeniowe" 2010, nr 2, s. 55.

${ }^{9} \mathrm{Na}$ ten aspekt zwraca uwagę M. Kamiński, Ubezpieczenia wzajemne a ubezpieczenia komercyjne, „Rozprawy Ubezpieczeniowe” 2013, nr 2.

${ }^{10}$ „Art. 111.1. Jeżeli statut towarzystwa ubezpieczeń wzajemnych nie stanowi inaczej, uzyskanie członkostwa w towarzystwie ubezpieczeń wzajemnych jest związane z zawarciem umowy ubezpieczenia, a jego utrata - z wygaśnięciem stosunku ubezpieczenia.

2. Statut towarzystwa ubezpieczeń wzajemnych może przewidywać, że towarzystwo ubezpieczeń wzajemnych będzie ubezpieczało także osoby niebędące członkami towarzystwa. Osoby te nie mogą być zobowiązane do udziału w pokrywaniu straty towarzystwa przez wnoszenie dodatkowej składki ubezpieczeniowej.

3. Składki od osób, o których mowa w ust. 2, nie mogą stanowić więcej niż 10\% składki przypisanej brutto towarzystwa ubezpieczeń wzajemnych".

${ }^{11}$ Tak P. Stopnicki, komentarz do art. 102, [w:] Ustawa o działalności ubezpieczeniowej i reasekuracyjnej. Komentarz, red. P. Czublun, Warszawa 2016. 
towarzystwa jako konsumenta spełniającego przesłanki wskazane w art. $22^{1}$ k.c., tj. osoby fizycznej dokonującej czynności prawnej (zawarcia umowy ubezpieczenia) ${ }^{12}$. Istotny wydaje się przy tym art. $805 \S 1$ k.c. ${ }^{13}$, z którego wynika, że jedną ze stron umowy ubezpieczenia musi być przedsiębiorca (zgodnie z art. $43^{1}$ k.c.), który w zakresie swojego przedsiębiorstwa zawiera umowy ubezpieczenia ${ }^{14}$. Działalność TUW jako ubezpieczyciela ma zatem charakter profesjonalny, a umowa ubezpieczenia jest umową odpłatną.

Wskazane argumenty — mimo specyfiki podmiotów, jakimi są towarzystwa ubezpieczeń wzajemnych - pozwalają na zakwalifikowanie TUW do kategorii przedsiębiorców (podmiotów prowadzących działalność gospodarczą).

\section{ZASADY NIEPOŁĄCZALNOŚCI MANDATU POSŁA DO PARLAMENTU EUROPEJSKIEGO}

1. Zgodnie z art. 7 ust. 1 i 2 aktu dotyczącego wyboru członków Parlamentu Europejskiego w powszechnych wyborach bezpośrednich, załączonego do decyzji Rady 76/787/EWWiS, EWG, Euratom z dnia 20 września 1976 r. (Dz.Urz. UE. L 1976, nr 278, s. 5) mandatu członka Parlamentu Europejskiego nie można łączyć z funkcją członka rządu państwa członkowskiego oraz członkostwem w parlamencie krajowym. Pozostałe zakazy ustanowione w art. 7 ust. 1 aktu dotyczą funkcji i stanowisk w organach i instytucjach Unii Europejskiej ${ }^{15}$. Ponadto w art. 7 ust. 3 aktu przewidziano, że zasady dotyczące zakazu łączenia funkcji każde państwo członkowskie może rozszerzyć w prawie krajowym.

12 Ibidem, P. Stopnicki zwraca uwagę na to, że w towarzystwach ubezpieczeń wzajemnych, w których ubezpieczający wraz z zawarciem umowy ubezpieczenia staje się członkiem towarzystwa: „Z uwagi na raczej formalny niż rzeczywisty charakter jego uprawnień «właścicielskich» wobec towarzystwa - nie ma podstaw, aby różnicować sytuację tych osób w stosunku do konsumentów, którzy zdecydowali się na skorzystanie z ochrony ubezpieczeniowej oferowanej przez podmioty działające w formie spółki akcyjnej”.

13 „§1. Przez umowę ubezpieczenia ubezpieczyciel zobowiązuje się, w zakresie działalności swego przedsiębiorstwa, spełnić określone świadczenie w razie zajścia przewidzianego w umowie wypadku, a ubezpieczający zobowiązuje się zapłacić składkę".

${ }^{14}$ Vide J.M. Kondek, [w:] Kodeks cywilny. Komentarz, red. K. Osajda, Lex 2019, który stwierdza również, że: „Umowa ubezpieczenia może zostać zawarta tylko w ramach działalności przedsiębiorstwa ubezpieczyciela".

${ }^{15}$ Mandatu członka PE nie można łączyć z funkcją: członka Komisji Wspólnot Europejskich, sędziego, rzecznika generalnego lub sekretarza Trybunału Sprawiedliwości Wspólnot Europejskich lub Sądu Pierwszej Instancji, członka zarządu Europejskiego Banku Centralnego, członka Trybunału Obrachunkowego Wspólnot Europejskich, Rzecznika Praw Obywatelskich Wspólnot Europejskich, członka Komitetu Ekonomiczno-Społecznego Europejskiej Wspólnoty Gospodarczej i Europejskiej Wspólnoty Energii Atomowej, członka Komitetu Regionów, członka komitetów lub innych organów utworzonych na mocy Traktatów ustanawiających Europejską Wspólnotę Gospodarczą i Europejską Wspólnotę Energii Atomowej w celu zarządzania funduszami Wspólnot lub wykonywania stałych bezpośrednich zadań administracyjnych, członka Rady Dyrektorów, Komitetu Zarządzającego lub pracownika Europejskiego Banku Inwestycyjnego, czynnego urzędnika lub pracownika instytucji Wspólnot Europejskich lub wyspecjalizowanych organów przy nich ustanowionych lub Europejskiego Banku Centralnego. 
W polskim systemie prawnym zasady, o których mowa w art. 7 ust. 3 aktu, zostały ustanowione w ustawie z dnia 5 stycznia 2011 r. kodeks wyborczy (Dz.U. z 2019 r. poz. 684; dalej: k.w.). W art. 333 k.w. proklamowano zasadę, zgodnie z którą „Mandatu posła do Parlamentu Europejskiego nie można łączyć ze sprawowaniem stanowiska lub pełnieniem funkcji określonych w przepisach prawa Unii Europejskiej”, a w art. 334 $\S 1$ powtórzono, wynikającą z art. 7 ust. 2 aktu, zasadę, że „mandatu posła do Parlamentu Europejskiego nie można łączyć ze sprawowaniem mandatu posła na Sejm albo senatora”. Ponadto zgodnie z art. $334 \S 2$ k.w., „poseł do Parlamentu Europejskiego nie może być jednocześnie w Rzeczypospolitej Polskiej członkiem Rady Ministrów ani sekretarzem stanu oraz zajmować stanowiska lub pełnić funkcji, których, stosownie do przepisów Konstytucji Rzeczypospolitej Polskiej albo ustaw, nie można łączyć ze sprawowaniem mandatu posła na Sejm albo senatora".

2. Pozostawanie członkiem Rady Nadzorczej TUW nie jest objęte żadnym ze wskazanych zakazów. TUW jako przedsiębiorca będący podmiotem działającym w formie prawnej, jaką jest towarzystwo ubezpieczeń wzajemnych, nie należy do kategorii podmiotów, do których można stosować zakaz formalnej niepołączalności mandatu.

Zarówno w piśmiennictwie ${ }^{16}$, jak również w działalności opiniodawczej Biura Analiz Sejmowych ${ }^{17}$ przyjmuje się, że do posłów do PE mają zastosowanie jedynie te zakazy, które dotyczą sprawowania przez posła na Sejm lub senatora określonych stanowisk i funkcji w ramach tzw. niepołączalności formalnej mandatu. W związku $\mathrm{z}$ tym posłowie do PE nie podlegają zakazom i ograniczeniom związanym $\mathrm{z}$ aktywnością gospodarczą, zwanymi niepołączalnością materialną. Niepołączalność (incompatibilitas) formalna rozumiana jest jako zakaz łączenia mandatu parlamentarnego z pełnieniem określonych funkcji i stanowisk państwowych wymienionych przede wszystkim w art. 102, 103 i 132 konstytucji oraz art. 30 ustawy z dnia 9 maja 1996 r. o wykonywaniu mandatu posła i senatora (Dz.U. z 2018 r. poz. 1799; dalej: ustawa poselsko-senatorska) oraz w innych ustawach (np. w ustawie o samorządzie gminnym, ustawie o Najwyższej Izbie Kontroli czy o Prokuratorii Generalnej Skarbu Państwa), a materialna jako zakaz prowadzenia określonej przez prawo działalności ${ }^{18}$, czyli działalności gospodarczej, o której mowa w art. 107 konstytucji oraz art. 34 ustawy poselsko-senatorskiej.

${ }^{16}$ S. Jaworski, J. Zbieranek, komentarz do art. 334, [w:] Kodeks wyborczy. Komentarz, red. K.W. Czaplicki et al., Lex 2018: „Przepisy art. 333 i 334 wprowadzają instytucje niepołączalności formalnej (incompatibilitas)".

17 Vide m.in. P. Chybalski, „Opinia prawna w sprawie łączenia mandatu posła do Parlamentu Europejskiego z zatrudnieniem na stanowisku dyrektora oddziału Totalizatora Sportowego oraz ze sprawowaniem mandatu radnego rady miasta", BAS-WAUiP-1230/09 (niepublikowana) oraz I. Galińska-Rączy, „Opinia prawna w sprawie możliwości łączenia mandatu posła do Parlamentu Europejskiego z członkostwem w Zarządzie Stowarzyszenia «Dolnośląska Organizacja Turystyczna»”, BAS-WAL-1654/09 (niepublikowana).

${ }^{18}$ L. Garlicki, komentarz do art. 103 i art. 107, [w:] Konstytucja Rzeczypospolitej Polskiej. Komentarz, red. L. Garlicki, Warszawa 2001. 
W opinii prawnej w sprawie możliwości łączenia mandatu posła do Parlamentu Europejskiego z członkostwem w Zarządzie Stowarzyszenia „Dolnośląska Organizacja Turystyczna” 19 stwierdzono: „Sformułowanie «zajmować stanowiska lub pełnić funkcję» należy odnosić do formalnej niepołączalności mandatu parlamentarnego. Pogląd ten potwierdza zarówno wykładnia językowa art. 103 Konstytucji, w którym w ust. 1 i 2 wymieniono funkcje, stanowiska i rodzaje zatrudnienia i służby niepołączalne z mandatem, jak i ust. 3, który stanowi: Inne przypadki zakazu łączenia mandatu poselskiego z funkcjami publicznymi oraz zakazu jego sprawowania może określić ustawa, jak i porównanie tego przepisu z treścią art. 107 ust. 1 Konstytucji, w którym wyraźnie mówi się o «prowadzeniu działalności gospodarczej z osiąganiem korzyści z majątku Skarbu państwa lub samorządu terytorialnego»". Porównanie treści art. 103 i art. 107 ustawy zasadniczej uprawnia do postawienia tezy, że ustawodawca konstytucyjny w sposób ewidentny rozróżnia niepołączalność mandatu z pełnieniem określonych funkcji (stanowisk, zatrudnienia) od zakazów i ograniczeń w zakresie działalności gospodarczej prowadzonej przez parlamentarzystów.

Jako pomocną w interpretacji art. 103 (a pośrednio art. 107 Konstytucji), należy przytoczyć następującą wykładnię tego przepisu, dokonaną przez Trybunał Konstytucyjny w wyroku z dnia 20 kwietnia 2004 r. (sygn. akt K 45/02 OTK ZU 2004/4A/30): Konstytucja z 1997 r. dokonała systemowej zmiany w zakresie niepołączalności mandatu parlamentarnego z innymi rodzajami działalności publicznej (art. 103 ust. 1 regulujący status posła, na mocy art. 108 Konstytucji odnosi się do senatorów). Obok zakazu łączenia mandatu parlamentarnego z określonymi funkcjami — Prezesa Narodowego Banku Polskiego, Prezesa Najwyższej Izby Kontroli, Rzecznika Praw Obywatelskich, Rzecznika Praw Dziecka i ich zastępców, członka Rady Polityki Pieniężnej, członka Krajowej Rady Radiofonii i Telewizji oraz ambasadora, wprowadziła również zakaz sprawowania mandatu parlamentarnego przez osoby zatrudnione w Kancelariach Sejmu, Senatu i Prezydenta oraz w administracji rządowej. Przyjęta w art. 103 ust. 1 Konstytucji z 1997 r. regulacja zbliżyła to rozwiązanie do obowiązującego pod rządami Konstytucji z 1921 r. zakazu obejmowania przez posłów i senatorów „płatnej służby państwowej”. Wprowadzenie zakazu zatrudniania członków parlamentu w strukturach administracji państwowej ma zapobiegać wkraczaniu ich w ramy stosunków służbowych w obrębie administracji, charakteryzujących się stosunkiem podległości i odpowiedzialności wobec zwierzchnika służbowego.

Zupełnie inny charakter ma zakaz ustanowiony w art. 107 Konstytucji RP oraz art. 34 ustawy poselsko-senatorskiej ${ }^{20}$. Przepis art. 107 Konstytucji normuje tzw. konflikt interesów, stanowiąc zarazem istotny element regulacji antykorpucyjnych na gruncie prawa parlamentarnego (obok oświadczeń o stanie majątkowym, Rejestru Korzyści i zawiadamia Marszałka o zamiarze podjęcia dodatkowych zajęć, wprowadzonym w art. 33

19 I. Galińska-Rączy, op. cit.

${ }^{20} \mathrm{~W}$ literaturze nie ma zgodności co do tego, że zakres przedmiotowy art. 107 ust. 1 konstytucji został dookreślony w art. 34 ustawy poselsko-senatorskiej (L. Garlicki, op. cit.; P. Winczorek, Komentarz do Konstytucji Rzeczypospolitej Polskiej z dnia 2 kwietnia 1997 r., Warszawa 2000, s. 140). 
ustawy poselsko-senatorskiej). Tego typu zakaz, jako tworzący odrębną instytucję prawną można uznawać za niemieszczący się w pojęciu incompatibilitas ${ }^{21}$. Z poglądem tym należy się zgodzić, jeśli weźmiemy pod uwagę analogiczne zakazy (a dokładniej konsekwencje ich nieprzestrzegania) obowiązujące radnych. W ustawie z dnia 16 lipca 1998 r. Ordynacja wyborcza do rad gmin, rad powiatów i sejmików województw, w art. 190 ust. 1 pkt 2a czytamy:

„Wygaśnięcie mandatu radnego następuje wskutek: [...]

2a) naruszenia ustawowego zakazu łączenia mandatu radnego $\mathrm{z}$ wykonywaniem określonych w odrębnych przepisach funkcji lub działalności.

Jak widać, ustawodawca w sposób ewidentny rozróżnia pełnienie (wykonywanie) «funkcji» oraz prowadzenie «działalności», mając na względzie:

- $\mathrm{z}$ jednej strony: ustawowe zakazy łączenia mandatu radnego $\mathrm{z}$ wykonywaniem określonych funkcji i zatrudnienia (ustawy samorządowe zakazują radnemu łączenia mandatu ze statusem pracownika urzędu jednostki samorządowej odpowiednio urzędu gminy, starostwa powiatowego i urzędu marszałkowskiego oraz z pełnieniem funkcji kierownika i zastępcy kierownika jednostki organizacyjnej tej jednostki samorządowej),

— zaś z drugiej: prowadzenie przez radnych działalności gospodarczej na własny rachunek lub wspólnie z innymi osobami z wykorzystaniem mienia jednostki samorządowej, w której radny uzyskał mandat, a także zarządzanie taką działalnością lub bycie przedstawicielem czy pełnomocnikiem w prowadzeniu takiej działalności, jak również bycie członkami władz zarządzających lub kontrolnych i rewizyjnych oraz pełnomocnikami spółek handlowych z udziałem osób prawnych danej jednostki samorządowej lub przedsiębiorców, w których uczestniczą takie osoby.

Na podstawie dotychczasowych rozważań, należy przyjmować, że w dyspozycji art. 6 ust. 2 Ordynacji wyborczej do Parlamentu Europejskiego nie mieści się naruszenie art. 107 ust. 1 Konstytucji RP ani też art. 34 ustawy poselsko-senatorskiej".

3. Powyższe stanowisko wydaje się uzasadnione również wobec aktualnie obowiązujących zakazów wynikających z kodeksu wyborczego, w tym przede wszystkim $\mathrm{z}$ uwagi na różnice $\mathrm{w}$ treści przepisów ustalających przesłanki wygaśnięcia mandatu. W art. $383 \S 1$ pkt 5 k.w. przewidziano wygaśnięcie mandatu radnego wskutek naruszenia ustawowego zakazu łączenia mandatu radnego z wykonywaniem określonych w odrębnych przepisach funkcji lub działalności (analogiczną treść ma art. $492 \S 1$ pkt 5 k.w., w którym mowa o wygaśnięciu mandatu wójta wskutek: „,naruszenia ustawowych zakazów łączenia funkcji wójta $\mathrm{z}$ wykonywaniem funkcji lub prowadzenia działalności gospodarczej, określonych w odrębnych przepisach"), a w art. 247 § 1 pkt 5 k.w. przewidziano wygaśnięcie mandatu posła w przypadku ,zajmowania w dniu wyborów stanowiska lub funkcji, których stosownie do przepisów Konstytucji Rzeczypospolitej Polskiej albo ustaw nie można łączyć z mandatem posła".

${ }^{21}$ Vide D. Lis-Staranowicz, Niepołaczalność mandatu parlamentarnego w polskim prawie konstytucyjnym, Warszawa 2005, rozdz. I, pkt 1. 
Wobec braku wyraźnej podstawy ustawowej do stosowania wobec eurodeputowanych zakazów w ramach materialnej niepołączalności mandatu, nawet jeśli zakwalifikujemy TUW do kategorii przedsiębiorców, do rozważanego stanu faktycznego nie znajdą zastosowania zakazy wynikające z art. 34 ust. 1 i 2 ustawy poselsko-senatorskiej ${ }^{22}$.

\section{PODSUMOWANIE}

Towarzystwo Ubezpieczeń Wzajemnych, będące podmiotem działającym w obecnej formie prawnej, nie należy do kategorii podmiotów, które są objęte zakazami formalnej niepołączalności mandatu, czyli zakazami ustalonymi m.in. w art. 103 konstytucji oraz art. 30 ustawy poselsko-senatorskiej. Posłów do PE nie obowiązują zakazy związane z niepołączalnością materialną mandatu (odnoszące się do działalności gospodarczej ustanowione w art. 34 ustawy poselsko-senatorskiej, w tym m.in. zakazy członkostwa we władzach podmiotów prowadzących taką działalność). W związku z tym nie ma przeszkód, aby osoba, która uzyskała mandat posła do PE, pozostawała członkiem Rady Nadzorczej Towarzystwa Ubezpieczeń Wzajemnych.

Irena Galińska-Raczy*

* Irena Galińska-Rączy, Biuro Analiz Sejmowych, irena.galinska-raczy@sejm.gov.pl, https://orcid.org/0000-0003-3586-0126

22 „Art. 34. 1. Posłowie i senatorowie nie mogą prowadzić działalności gospodarczej na własny rachunek lub wspólnie z innymi osobami z wykorzystaniem mienia państwowego lub komunalnego, a także zarządzać taką działalnością lub być przedstawicielem czy pełnomocnikiem w prowadzeniu takiej działalności. 2. Posłowie i senatorowie nie mogą być członkami władz zarządzających lub kontrolnych i rewizyjnych ani pełnomocnikami handlowymi przedsiębiorców z udziałem państwowych lub komunalnych osób prawnych lub przedsiębiorców, w których uczestniczą takie osoby. Wybór lub powołanie posła lub senatora do tych władz jest z mocy prawa nieważny". 